\title{
Pengembangan Soal Uraian Berbasis Indikator Kemampuan Berpikir Tingkat Tinggi pada Konsep Sistem Pencernaan pada Manusia untuk Siswa Kelas VIII SMP/Mts
}

\author{
Tyas Putri Utami*, Sjaifuddin, Liska Berlian \\ Program Studi Pendidikan IPA, Fakultas Keguruan dan Ilmu Pendidikan, \\ Universitas Sultan Ageng Tirtayasa \\ Jalan Ciwaru Raya, No. 25, Cipare, Serang 42117, Banten, Indonesia \\ *Email: tyasputri061@gmail.com
}

DOI: https://doi.org/10.33369/pendipa.6.1.129-135

\begin{abstract}
The problem in this study comes from research data which shows that the students' higher-order thinking skills are still low and the teacher has not developed an optimal higher-order thinking skills ability test instrument. The purpose of this study was to develop and determine the level of validity of the test instrument for higher-order thinking skills on the concept of the digestive system in graders of $8^{\text {th }}$ junior high school. This study uses research and development which refers to the model of development of Borg and Gall with the restriction to five steps which includes potentials and problems, data collections, design of product, product of validation, and product of revision. The product produced in this research and development is in the form of a test instrument for higher-order thinking skills on the concept of the digestive system in graders of $8^{\text {th }}$ junior high school which consists of 27 questions. The results of the average percentage score of the 27 validation questions are $98 \%$ consisting of the validation results of material experts 99\%, evaluation experts 97\%, and educators 99\%. It can be concluded that the 27 questions developed $100 \%$ are in the very valid category.
\end{abstract}

Keywords: Research and development, higher-order thinking skills, digestive system in humans.

\begin{abstract}
ABSTRAK
Masalah dalam penelitian ini dilatarbelakangi oleh data yang menunjukkan bahwa kemampuan berpikir tingkat tinggi siswa masih rendah dan guru belum mengembangkan instrumen tes kemampuan berpikir tingkat tinggi secara optimal. Penelitian ini bertujuan untuk mengembangkan dan mengetahui tingkat kevalidan soal uraian berbasis indikator kemampuan berpikir tingkat tinggi pada konsep sistem pencernaan pada manusia untuk siswa kelas VIII SMP/MTs. Penelitian ini menggunakan metode penelitian dan pengembangan (research and development) yang merujuk kepada model penelitian dan pengembangan Borg and Gall dengan dibatasi menjadi lima langkah penelitian dan pengembangan yaitu, (1) potensi dan masalah, (2) pengumpulan informasi, (3) desain produk, (4) validasi produk, dan (5) revisi produk. Penelitian dan pengembangan ini menghasilkan produk yang berupa soal uraian berbasis indikator kemampuan berpikir tingkat tinggi pada konsep sistem pencernaan pada manusia untuk siswa kelas VIII SMP/MTs yang berjumlah 27 butir soal. Hasil persentase skor rata-rata keseluruhan validasi 27 butir soal tersebut sebesar 98\% yang meliputi hasil validasi ahli materi 99\%, ahli evaluasi 97\%, dan pendidik 99\%. Jadi dapat disimpulkan bahwa 27 butir soal uraian yang dikembangkan 100\% berada dalam interpretasi sangat valid.
\end{abstract}

Kata kunci: Penelitian pengembangan, berpikir tingkat tinggi, sistem pencernaan pada manusia. 


\section{PENDAHULUAN}

Kehidupan abad 21 ditandai dengan adanya permasalahan yang kompleks dan rumit. Berkembangnya informasi yang cepat dan melimpah serta teknologi yang semakin canggih turut mempengaruhi kehidupan abad 21 termasuk dalam dunia kerja. Hal tersebut menjadi dasar bahwa pendidikan harus mampu menciptakan lulusan yang adaptif. Langkah yang dapat dilakukan untuk menciptakan lulusan yang adaptif adalah mengembangkan kemampuan berpikir melalui proses pembelajaran agar siswa memiliki kompetensi dalam memecahkan masalah yang berkaitan dengan kehidupan sehari-hari (Haryanti dan Saputra, 2019). Hal ini senada dengan pernyataan Richmond (2007) yang mengungkapkan bahwa modal kuat bagi siswa dalam menghadapi permasalahan abad 21 yang kompleks adalah kemampuan berpikir yang baik. Yildirim dan Ozkarahman (2011) menegaskan bahwa cara mengembangkan kemampuan berpikir melalui suatu pengkondisian untuk berpikir. Oleh sebab itu untuk mengikuti perkembangan ilmu pengetahuan dan teknologi pada abad 21, siswa membutuhkan proses latihan berpikir yang berorientasi pada kemampuan berpikir pada tingkat kognitif yang lebih tinggi.

Kemampuan berpikir yang penting dimiliki siswa pada abad 21 adalah kemampuan berpikir tingkat tinggi. Hal ini selaras dengan pernyataan Yen dan Halili (2015) yang mengungkapkan bahwa kemampuan berpikir tingkat tinggi merupakan tujuan utama pembelajaran abad 21 . Pendapat tersebut didukung oleh pernyataan Greenhill (2009) "Teaching critical thinking in schools is one of the main topics in the discussion regarding so called $21^{\text {st }}$ century skills". Proses pembelajaran memerlukan integrasi content knowledge melalui kegiatan pembelajaran yang membentuk kemampuan berpikir tingkat tinggi untuk memecahkan masalah pada setiap subjek dan tingkatan pendidikan (Trilling dan Fadel, 2009). Pendapat tersebut didukung oleh Taksonomi Bloom yang telah direvisi yang mencakup ranah kognitif $\mathrm{C} 1$ (mengingat), $\mathrm{C} 2 \quad$ (memahami), $\mathrm{C} 3$ (mengaplikasikan), C4 (menganalisis), C5 (mengevaluasi), dan C6 (menciptakan) (Anderson dan Krathwohl, 2001). Pohl (2000) mengatakan bahwa ranah kognitif Taksonomi
Bloom yang meliputi C4 (menganalisis), C5 (mengevaluasi), dan C6 (menciptakan) adalah indikator kemampuan berpikir tingkat tinggi.

Menurut Heong, et al. (2011), kemampuan berpikir pada tingkat yang lebih tinggi daripada hanya sekadar menghapal fakta atau menjelaskan suatu informasi kepada seseorang merupakan definisi kemampuan berpikir tingkat tinggi. Kemampuan berpikir tingkat tinggi dapat dikembangkan melalui pembelajaran dengan cara penyajian materi berupa masalah yang berkaitan dengan fenomena yang terjadi dalam kehidupan sehari-hari. Sejalan dengan keperluan tersebut, Wibowo dan Suhandi (2013) mengatakan bahwa Ilmu Pengetahuan Alam (IPA) merupakan mata pelajaran yang bukan hanya menuntut siswa untuk menguasai pengetahuan berupa konsepkonsep, fakta-fakta, atau prinsip-prinsip saja, melainkan IPA juga menuntut siswa untuk mencari tahu tentang alam secara sistematis melalui proses penemuan. Dapat dikatakan bahwa dalam pembelajaran IPA, siswa dituntut untuk menemukan solusi terkait masalah yang disajikan dalam pembelajaran IPA itu sendiri.

Mata pelajaran IPA bertujuan untuk mengembangkan kemampuan berpikir tingkat tinggi pada siswa untuk memperoleh kompetensi lanjut dalam mengembangkan ilmu pengetahuan dan teknologi. Oleh karena itu, perlu transformasi sistem belajar IPA dari belajar secara dangkal ke belajar secara mendalam atau kompleks, dari sekedar belajar menghapal ke belajar menganalisis, serta dari orientasi transfer ilmu pengetahuan ke pengembangan kompetensi. Bila transformasi sistem belajar tersebut belum dilaksanakan maka akan menimbulkan berbagai masalah. Selain hasil belajar yang rendah, proses pembelajaran yang tidak mengungkap kemampuan berpikir tingkat tinggi siswa merupakan salah satu masalah yang sering muncul dalam pembelajaran IPA. Akibatnya, siswa tidak mampu bersaing dalam bidang keilmuan untuk memunculkan gagasan-gagasan baru.

Laporan hasil Programme for International Student Asssesment (PISA) pada tahun 2012 dan 2015 menunjukkan rendahnya prestasi belajar siswa. Indonesia berada di peringkat ke-64 dari 65 negara yang berpartisipasi mengikuti tes pada laporan PISA tahun 2012. Data terbaru yang dirilis oleh PISA pada hasil penelitian tahun 
2015, Indonesia berada di peringkat ke-62 dari 72 negara yang berpartisipasi mengikuti tes. Posisi ini bahkan tertinggal dari Vietnam yang berada di peringkat 10 besar dan Singapur yang berhasil menduduki peringkat pertama. Sistem penilaian PISA mengembangkan instrumen tes matematika dan sains yang sebagiannya berbasis indikator kemampuan berpikir tingkat tinggi dan menekankan pada pemecahan masalah.

Rendahnya peringkat Indonesia pada PISA tidak terjadi begitu saja melainkan ada permasalahan yang melatarbelakanginya. Menurut Aydin dan Yilmaz (2010), untuk mengembangkan kemampuan berpikir tingkat tinggi siswa, guru harus memiliki pengetahuan dan keahlian dalam mengembangkan instrumen tes yang berupa soal-soal. Berdasarkan hasil wawancara dengan guru bidang studi IPA Terpadu di salah satu SMP Negeri di Jakarta Utara ditemukan bahwa sekolah tersebut belum melakukan pengembangan soal-soal yang menjadi instrumen khusus untuk mengukur kemampuan berpikir tingkat tinggi siswa secara optimal. Instrumen yang masih sering digunakan guru dalam pembelajaran di sekolah tersebut masih berupa Traditional Assessment (Tes Tulis) yang berbentuk Multiple Choice (Pilihan Ganda) biasa. Tes tulis pilihan ganda yang digunakan hanya mengukur kemampuan $\mathrm{C} 1$ (mengingat), C2 (memahami), dan C3 (menerapkan). Ketiga tingkatan Taksonomi Bloom tersebut baru mengukur Kemampuan Berpikir Tingkat Rendah (Lower Order Thinking Skill (LOTS)) belum mengukur Kemampuan Berpikir Tingkat Tinggi (Higher Order Thinking Skill (HOTS)). Oleh karena itu, perlu dikembangkan soal-soal sebagai instrumen tes untuk mengukur kemampuan berpikir tingkat tinggi siswa.

Hal tersebut didukung pula oleh beberapa jurnal penelitian internasional terkait pengembangan instrumen tes berupa soal-soal berbasis indikator kemampuan berpikir tingkat tinggi. Beberapa jurnal penelitian internasional yang terkait diantaranya adalah penelitian yang dilakukan oleh Barnett dan Francis (2012), Erfianti, et al. (2019), serta Karim dan Puteh (2019). Ketiga penelitian tersebut sepakat bahwa untuk mengetahui kemampuan berpikir tingkat tinggi siswa dibutuhkan pengembangan instrumen tes yang valid berdasarkan indikator kemampuan berpikir tingkat tinggi. Konsep sistem pencernaan pada manusia yang digunakan dalam penelitian ini menjadi letak perbedaan penelitian ini dengan penelitian sebelumnya.

Alasan pemilihan konsep sistem pencernaan pada manusia karena materi tersebut membutuhkan kemampuan pemecahan masalah dengan pemahaman konsep secara mendalam yang melibatkan kemampuan berpikir tingkat tinggi. Konsep sistem pencernaan manusia membahas tentang zat makanan, uji bahan makanan, organ pencernaan, enzim pencernaan, penyakit yang berhubungan dengan sistem pencernaan, serta upaya menjaga kesehatan sistem pencernaan sehingga dekat dengan kehidupan siswa sehari-hari. Selain itu, konsep sistem pencernaan pada manusia juga mencakup keterpaduan IPA yang di dalamnya meliputi bidang kajian ilmu biologi, kimia, dan fisika. Oleh karena itu pengembangan soal-soal uraian berbasis indikator kemampuan berpikir tingkat tinggi dengan mengangkat konsep sistem pencernaan pada manusia penting dilakukan guna membantu siswa dalam memahami konsep secara mendalam untuk memecahkan masalah yang ditemukan dalam kehidupan sehari-hari.

Berdasarkan masalah yang telah diuraikan, maka dilakukan penelitian yang berjudul "Pengembangan Soal Uraian Berbasis Indikator Kemampuan Berpikir Tingkat Tinggi pada Konsep Sistem Pencernaan pada Manusia untuk Siswa Kelas VIII SMP/MTs."

\section{METODE PENELITIAN}

\section{Waktu dan Lokasi Penelitian}

Penelitian ini dilaksanakan pada bulan Maret sampai dengan Mei tahun 2021 di Kampus C FKIP Universitas Sultan Ageng Tirtayasa dan SMPN 152 Jakarta Utara.

\section{Subjek Penelitian}

Subjek pada penelitian ini adalah 27 butir soal uraian yang disusun berdasarkan indikator kemampuan berpikir tingkat tinggi konsep sistem pencernaan pada manusia untuk siswa kelas VIII SMP/MTs.

\section{Rancangan Penelitian}

Metode yang digunakan dalam penelitian ini adalah kualitatif dengan desain penelitian dan pengembangan atau Research and Development (R\&D) yang bertujuan untuk menghasilkan produk tertentu. Sukmadinata (2006) menyatakan bahwa R\&D merupakan suatu proses atau 
langkah-langkah untuk mengembangkan suatu produk baru atau menyempurnakan suatu produk yang telah ada dan dapat dipertanggungjawabkan. Tujuan dari produk yang dihasilkan R\&D dapat berguna bagi masyarakat luas (Sugiyono, 2014).

Prosedur penelitian yang dilakukan pada penelitian ini diaptasi dari model pengembangan Borg and Gall tersebut dengan pembatasan. Membatasi langkah penelitian diperbolehkan dalam penelitian berskala kecil (Emzir, 2013). Pernyataan tersebut didukung oleh Sukmadinata (2009) bahwa dimungkinkan memodifikasi dan menyederhanakan langkah-langkah penelitian tanpa mengurangi esensinya.

\section{Teknik Pengumpulan Data}

Teknik pengumpulan data yang dilakukan pada penelitian ini menggunakan lembar validasi ahli berupa angket yang ditujukan kepada validator instrumen tes yang dikembangkan yaitu ahli materi dan praktisi. Menurut Widyoko (2016) angket adalah teknik pengumpulan data yang dilakukan dengan memberikan serangkaian pertanyaan atau pernyataan tertulis yang dalam penelitian ini ditujukan kepada validator. Respon validator pada lembar angket dituangkan ke dalam skala 1-4. Penilaian instrumen penelitian ini dilakukan dengan cara membagi menjadi 4 skala pada masing-masing pernyataan. Skala yang digunakan yaitu Sangat Kurang Baik (SKB) dengan skor 1, Kurang Baik (KB) dengan skor 2, Baik (B) dengan skor 3, dan Sangat Baik (SB) dengan skor 4.

\section{Teknik Analisis Data}

Data kualitatif dalam penelitian ini diperoleh berdasarkan hasil validasi produk berupa kritik dan saran dari validator terhadap soal uraian kemampuan berpikir tingkat tinggi yang dikembangkan. Kritik dan saran tersebut dituangkan pada lembar validasi yang telah peneliti buat. Kritik dan saran dari validator digunakan peneliti untuk merevisi produk sehingga menghasilkan soal kemampuan berpikir tingkat tinggi yang layak digunakan.

Data kuantitatif dalam penelitian ini diperoleh berdasarkan respon yang diberikan validator yang dituangkan dalam bentuk skor pada lembar validasi berupa angket. Lembar angket validasi dalam penelitian ini mengacu pada skala likert dengan skor 1-4 dalam bentuk pernyataan yang disajikan pada Tabel 1 berikut.
Tabel 1. Skala Likert

\begin{tabular}{cc}
\hline Pilihan Jawaban & Skor \\
\hline Sangat Baik (SB) & 4 \\
Baik (B) & 3 \\
Kurang Baik (KB) & 2 \\
Sangat Kurang Baik & 1 \\
\hline
\end{tabular}

Skor yang diperoleh kemudian dirata-ratakan menggunakan rumus sebagai berikut.

Keterangan:

$$
\bar{x}_{\text {国 }}=\frac{\sum x}{n}
$$

$x=$ skor rata-rata

$\sum x=$ jumlah skor

$n=$ jumlah responden

Setelah skor rata-rata diperoleh kemudian dipersentasekan menggunakan rumus sebagai berikut.

Rerata Persentase

$=\frac{\text { skor rata }- \text { rata } \times 100 \%}{\text { skor tertinggi }}$

Hasil persentase yang diperoleh kemudian diinterpretasikan untuk menentukan kevalidan produk yang dikembangkan. Interpretasi skala kevalidan produk dalam penelitian ini disajikan pada Tabel 2.

Tabel 2. Interpretasi Skala Kevalidan Produk

\begin{tabular}{cc}
\hline Persentase & Interpretasi \\
\hline $76 \%-100 \%$ & Sangat Valid \\
$51 \%-75 \%$ & Valid \\
$26 \%-50 \%$ & Kurang Valid \\
$0 \%-25 \%$ & Tidak Valid \\
\hline
\end{tabular}

(Akbar, 2013)

\section{HASIL DAN PEMBAHASAN \\ Potensi dan Masalah}

Kegiatan yang dilakukan pada tahap ini meliputi wawancara dan kajian pustaka. (1) Wawancara dilakukan dengan narasumber guru bidang studi IPA terpadu di salah satu SMP Negeri Jakarta Utara yang bertujuan untuk mengetahui masalah yang ada di sekolah tersebut, kebutuhan siswa, serta kurikulum yang digunakan. (2) Kajian pustaka terkait kemampuan berpikir tingkat tinggi yang kemudian diperoleh informasi bahwa kemampuan berpikir tingkat tinggi siswa di 
Indonesia masih rendah dengan dibuktikan oleh laporan PISA pada tahun 2012 dan 2015 sehingga perlu dikembangkan instrumen kemampuan berpikir tingkat tinggi.

\section{Pengumpulan Informasi}

Pengumpulan informasi dilakukan dengan cara beberapa tahap yaitu sebagai berikut:

a. Kajian Pustaka

Kajian pustaka dilakukan dengan cara mencari referensi yang relevan terkait produk yang dikembangkan yaitu instrumen tes kemampuan berpikir tingkat tinggi pada konsep sistem pencernaan pada manusia kelas VIII SMP/MTs, baik bersumber dari jurnal nasional maupun jurnal internasional.

b. Wawancara

Wawancara dilakukan bertujuan untuk mengetahui potensi dan masalah, kebutuhan siswa, dan kurikulum yang digunakan oleh sekolah tempat dilakukannya penelitian, serta menentukan konsep yang perlu dikembangkan menjadi sebuah produk. Adapun tahap potensi dan masalah telah dijabarkan pada langkah pengembangan sebelumnya. Setelah diketahui potensi dan masalah yang ada di sekolah, langkah selanjutnya adalah sebagai berikut.

1.) Menentukan KD dan konsep soal uraian berbasis indikator kemampuan berpikir tingkat tinggi. Berdasarkan hasil analisis dan wawancara, maka dapat ditentukan bahwa KD yang digunakan adalah 3.5 dan 4.5 kelas VIII SMP/MTs yang disajikan pada Tabel 3.

2.) Langkah selanjutnya adalah menyusun kisi-kisi soal uraian berbasis indikator kemampuan berpikir tingkat tinggi yang di dalamnya meliputi kompetensi dasar, nomor soal, indikator soal, pertanyaan, alternatif jawaban, level kognitif, dan proses kognitif. Komponen pada kisi-kisi soal menjadi acuan dalam membuat lembar soal dan rubrik penskoran.

\section{Desain Produk}

Desain produk yang dikembangkan berupa kisi-kisi soal uraian berbasis indikator kemampuan berpikir tingkat tinggi yang disesuaikan dengan kurikulum yang digunakan di sekolah, karakteristik siswa, kebutuhan guru, serta indikator kemampuan berpikir tingkat tinggi yang terdiri dari tiga level kognitif dan enam proses kognitif. Adapun Idikator kemampuan berpikir tinggi yang digunakan pada penelitian ini mengacu pada Taksonomi Bloom revisi Anderson dan Krathwohl (2001) yang disajikan pada Tabel 3 .

Tabel 3. Kemampuan Berpikir Tingkat Tinggi

\begin{tabular}{cc}
\hline Level Kognitif & Proses Kognitif \\
\hline \multirow{2}{*}{ C4 (Menganalisis) } & Membedakan \\
& Mengorganisasi \\
& Mengatribusikan \\
\hline C5 (Mengevaluasi) & Memeriksa \\
& Mengkritik \\
\hline C6 (Mencipta) & Merumuskan \\
\hline \multicolumn{2}{c}{ (Anderson dan Krathwohl, 2001) }
\end{tabular}

Tabel 4. Hasil Validasi oleh Ketiga Validator

\begin{tabular}{|c|c|c|c|c|}
\hline \multirow{2}{*}{$\begin{array}{c}\text { Nomor } \\
\text { Soal }\end{array}$} & \multicolumn{3}{|c|}{ Skor (\%) } & \multirow{2}{*}{ Interpretasi } \\
\hline & $\mathrm{V}_{1}$ & $\mathbf{V}_{2}$ & $\mathbf{V}_{3}$ & \\
\hline 1 & 100 & 98 & 100 & Sangat Valid \\
\hline 2 & 100 & 98 & 100 & Sangat Valid \\
\hline 3 & 100 & 98 & 100 & Sangat Valid \\
\hline 4 & 100 & 98 & 100 & Sangat Valid \\
\hline 5 & 100 & 95 & 100 & Sangat Valid \\
\hline 6 & 95 & 98 & 100 & Sangat Valid \\
\hline 7 & 100 & 98 & 100 & Sangat Valid \\
\hline 8 & 95 & 95 & 100 & Sangat Valid \\
\hline 9 & 100 & 95 & 100 & Sangat Valid \\
\hline 10 & 100 & 95 & 100 & Sangat Valid \\
\hline 11 & 100 & 98 & 100 & Sangat Valid \\
\hline 12 & 100 & 95 & 100 & Sangat Valid \\
\hline 13 & 95 & 95 & 100 & Sangat Valid \\
\hline 14 & 100 & 95 & 100 & Sangat Valid \\
\hline 15 & 95 & 98 & 100 & Sangat Valid \\
\hline 16 & 100 & 98 & 100 & Sangat Valid \\
\hline 17 & 95 & 95 & 91 & Sangat Valid \\
\hline 18 & 100 & 98 & 100 & Sangat Valid \\
\hline 19 & 100 & 95 & 100 & Sangat Valid \\
\hline 20 & 95 & 98 & 100 & Sangat Valid \\
\hline 21 & 100 & 98 & 100 & Sangat Valid \\
\hline 22 & 100 & 98 & 100 & Sangat Valid \\
\hline 23 & 100 & 98 & 100 & Sangat Valid \\
\hline 24 & 100 & 93 & 100 & Sangat Valid \\
\hline 25 & 100 & 100 & 100 & Sangat Valid \\
\hline 26 & 100 & 91 & 91 & Sangat Valid \\
\hline 27 & 100 & 100 & 100 & Sangat Valid \\
\hline \multicolumn{2}{|c|}{$\begin{array}{c}\text { Skor Rata- } \\
\text { rata (\%) }\end{array}$} & 99 & 97 & Sangat Valic \\
\hline \multicolumn{2}{|c|}{$\begin{array}{c}\text { Skor Rata- } \\
\text { rata } \\
\text { Keseluruhan } \\
\text { Validasi (\%) }\end{array}$} & & 98 & Sangat Valic \\
\hline
\end{tabular}




\section{Validasi Produk}

Tahap penelitian selanjutnya adalah validasi produk yang dilakukan oleh dua dosen Pendidikan IPA FKIP Untirta yang masingmasing berperan sebagai ahli materi dan ahli evaluasi, serta satu guru bidang studi IPA Terpadu SMP/MTs yang berperan sebagai pendidik. Instrumen tes yang dikembangkan divalidasi berdasarkan (1) aspek materi dan kemampuan berpikir tingkat tinggi yang mencakup 5 indikator penilaian dan divalidasi oleh ahli materi, (2) aspek konstruksi dan bahasa yang mencakup 11 indikator penilaian dan divalidasi oleh ahli evaluasi, dan (3) kesesuaian instrumen tes dengan pembelajaran yang dilakukan guru di sekolah yang mencakup 8 indikator penilaian dan divalidasi oleh pendidik. Hasil validasi oleh ketiga validator disajikan pada Tabel 4.

Berdasarkan data yang disajikan pada Tabel 4 diperoleh hasil skor rata-rata keseluruhan validasi 27 butir soal uraian kemampuan berpikir tingkat tinggi oleh tiga validator (ahli materi, ahli evaluasi, dan pendidik) sebesar $98 \%$ yang diinterpretasikan bahwa keseluruhan butir soal uraian yang dikembangkan sudah sangat valid baik dari aspek materi, konstruksi dan bahasa, serta kesesuaiannya dengan pembelajaran di sekolah.

\section{Revisi Produk}

Butir soal uraian kemampuan berpikir tingkat tinggi yang telah divalidasi oleh validator ahli materi, ahli evaluasi, dan pendidik memperoleh saran-saran yang membangun. Adapun saran-saran yang diberikan oleh ketiga validator tersebut dapat dilihat pada Tabel 5.

Tabel 5. Saran Perbaikan dari Validator

\begin{tabular}{cl}
\hline No. & \multicolumn{1}{c}{ Saran Perbaikan } \\
\hline 1. & Tuliskan kompetensi dasar pada kisi-kisi \\
2. & Perbaiki rubrik penskoran \\
3. & Perbaiki kalimat pertanyaan \\
4. & Perbaiki gambar untuk soal nomor 20 \\
5. & Perbaiki gambar untuk soal nomor 24 \\
6. & Tambahkan sumber stimulus untuk soal \\
& nomor 2 \\
7. & Perbaiki tata letak penulisan untuk soal \\
8. & Sesuaikan soal dan alternatf jawaban \\
9. & Hilangkan soal nomor 26 \\
\hline
\end{tabular}

\begin{tabular}{l}
\hline No. \\
\hline pada perintah yang menyertai soal \\
\hline Adapun revisi produk yang dilakukan \\
berdasarkan saran-saran dari validator disajikan \\
pada Tabel 6.
\end{tabular}

Tabel 6. Perbaikan Berdasarkan Saran Validator

\begin{tabular}{|c|c|}
\hline o. & - \\
\hline 1. & $\begin{array}{l}\text { Menambahkan tulisan kompetensi } \\
\text { dasar pada kisi-kisi yaitu KD } 3.5 \text { dan } \\
4.5\end{array}$ \\
\hline 2. & $\begin{array}{l}\text { Memperbaiki rubrik penskoran dengan } \\
\text { menambahkan kata kunci dan } \\
\text { menghilangkan kalimat "lengkap dan } \\
\text { tidak lengkap" }\end{array}$ \\
\hline 3. & $\begin{array}{l}\text { i kalimat pertanyaan untuk } \\
, 6,8,13,15 \text {, dan } 17\end{array}$ \\
\hline 4. & $\begin{array}{l}\text { Memperbaiki gambar dengan } \\
\text { mengganti gambar makanan yang } \\
\text { memiliki kandungan serupa }\end{array}$ \\
\hline 5. & $\begin{array}{l}\text { gambar nasi dengan } \\
\text { gambar nasi yang lebih jelas } \\
\text { hkan sumber stimulus untuk }\end{array}$ \\
\hline 6. & $\begin{array}{l}\text { kalimat "sunnah Rasulullah } \\
\text { menganjurkan kita untuk mengunyah } \\
\text { makanan secara perlahan sebanyak } 33 \\
\text { kali sebelum ditelan". }\end{array}$ \\
\hline 7 & $\begin{array}{l}\text { ki spasi untuk soal nomor } 8 \text {, } \\
t, 17,19 \text {, dan } 26\end{array}$ \\
\hline 8. & $\begin{array}{l}\text { ikan soal dan alternatif } \\
\text { gar sesuai dengan level C6 }\end{array}$ \\
\hline 9. & $\begin{array}{l}\text { Memperbaiki perintah pada soal } \\
\text { dengan langsung menyebutkan tabel, } \\
\text { gambar, atau pernyataan yang } \\
\text { dimaksud. }\end{array}$ \\
\hline
\end{tabular}

\section{KESIMPULAN}

Produk pengembangan soal uraian berbasis indikator kemampuan berpikir tingkat tinggi pada konsep sistem pencernaan pada manusia untuk siswa kelas VIII SMP/MTs dikembangkan dengan metode Research and Development (R\&D) dengan langkah penelitian dan pengembangan yang mengacu kepada model pengembangan Borg and Gall dengan pembatasan yang terdiri dari 5 tahapan yaitu: (1) potensi dan masalah, (2) pengumpulan informasi, (3) desain produk, (4) validasi produk, dan (5) revisi produk.

Hasil validasi soal uraian berbasis indikator kemampuan berpikir tingkat tinggi 
pada konsep sistem pencernaan pada manusia untuk siswa kelas VIII SMP/MTs memperoleh nilai rata-rata kevalidan secara keseluruhan yaitu $98 \%$ dengan interpretasi sangat valid. Berdasarkan hasil validasi oleh tiga validator yang terdiri dari ahli materi, ahli evaluasi, dan pendidik didapatkan hasil bahwa dari 27 butir soal uraian kemampuan berpikir tingkat tinggi yang dikembangkan keseluruhannya berada dalam kategori sangat valid yang apabila diubah ke dalam bentuk persen maka dapat dikatakan bahwa $100 \%$ butir soal berada pada kategori sangat valid.

\section{DAFTAR PUSTAKA}

Akbar, S. (2013). Instrumen Perangkat Pembelajaran. Bandung: Remaja Rosdakarya.

Anderson, L.W and Krathwohl, D.R. (2001). A Taxonomy for Learning, Teaching, and Assesing: A Revision of Bloom's Taxonomy of Educational Objectives. New York: Addison Wesley Longman, In.

Aydin, N. and Yilmaz, A. (2010). The Effect of Constructivist Approach in Chemistry Education on Students Higher Order Cognitive Skills. International Journal of Education. (39), 57-68.

Barnet, J.E and Francis, A.L. (2012). Using Higher Order Questionsto Foster Critical Thinking:A Classroom Study. International Journal of Experimental Educational Psychology.

Emzir. 2013. Metodologi Penelitian Pendidikan. Jakarta: PT Raja Grafindo Persada

Erfianti, L., Istiyono, E., and Kuswanto, $\mathrm{H}$. (2019). Developing Lup Instrument Test to Measure Higher Order Thinking Skills (HOTS) Bloomian for Senior High School Students. International Journal of Educational Research Review. 4(3) 320-329.

Greenhill. (2009). The Physics of Everyday Phenomena: A Conceptual Introduction to Physics, Sixth Edition. New York: Mc GrawHill Companies.

Haryanti, Y.D. dan Dudu S.S. (2019). Instrumen Penilaian Berpikir Kreatif pada Pendidikan Abad 21. Jurnal Cakrawala Pendas. Vol. 5, No. 2.
Heong, Y.M., Othman, W.B., Yunos, J. Bin, Kiong, T.T, Hassan, R. Bin, Mohaffyza, M., and Mohamad, B. (2011). The Level of Marzano HOTS among Technical Education Students. International Journal of Social Science and Humanity. 1(2), 121-125.

Karim, F.A. and Puteh, M. (2019). The Development of Higher Order Thinking Skills (HOTS) Assesment Instrument for Word Problems. International Journal of Academic Research in Business and Social Sciences. 9(6) 1079-1083.

Richmond, J.E.D. (2007). Bringing Critical Thinking to The Education of Developing Country Profesionals. International Journal of Education. 8(1):1-29.

Riduwan. (2009). Belajar Mudah Penelitian (untuk Guru, Karyawan, dan Peneliti Pemula). Bandung: CV Alfabeta.

Sugiyono. (2014). Metode Penelitian Kualitatif dan Kuantitatif dan $R \& D$. Bandung: Alfabeta.

Sukmadinata, N.S. (2006). Metode Penelitian Pendidikan. Bandung: Remaja Rosdakarya. (2009). Metode Penelitian Pendidikan. Bandung: Remaja Rosdakarya.

Trilling, B and Charles F. (2009). 21st Century Skills: Learning for Life in Our Times. San Fransisco: Jossey Bass.

Wibowo, F.C. dan A. Suhandi. (2013). Penerapan Model Science Creative Learning (SCL) Fisika Berbasis Proyek untuk Meningkatkan Hasil Belajar Kognitif dan Keterampilan Berpikir Kreatif. Jurnal Pendidikan IPA Indonesia. Vol. 2, No.1

Widyoko, E.P. (2016). Teknik Penyusunan Instrumen Penelitian. Yogyakarta: Pustaka Pelajar.

Yen, T.S. and Halili, S.H. (2015). Effective Teaching of Higher Order Thinking (HOT) in Education. The Online Journal of Distance Education and e-Learning (TOJDEL). Vol. 3, Issue 2.

Yildirim, B and Ozkarahman, S. (2011). Critical Thinking in Nursing Process and Education. International Journal of Humanities and Social Science. 1(13): 257-262. 